\title{
IMPLEMENTASI AUGMENTED REALITY UNTUK PENGENALAN HURUF HIJAIYAH AL-QURAN BERBASIS ANDROID
}

\author{
Billah Aktafi, Suryo Adi Wibowo, Abdul Wahid \\ Program Studi Teknik Informatika S1, Fakultas Teknologi Industri \\ Institut Teknologi Nasional Malang, Jalan Raya Karanglo km 2 Malang, Indonesia \\ aktafi6250@gmail.com
}

\begin{abstract}
ABSTRAK
Indonesia ialah salah satu negara dengan islam terbesar di dunia salah satu kewajiban umat islam ialah membaca Al-Quran, membaca Al-Quran sejak usia dini merupakan pembelajaran awal yang baik bagi setiap anak dengan mengenalkan huruf HijaIyah adalah salah satunya untuk pembelajaran awal namun sebagian anakanak usia 4 sampai 7 tahun lebih memilih dan asyik dengan smartphone mereka ketimbang dengan belajar membaca Al-Quran.

Dengan demikian anak-anak sangat sulit sekali membedakan huruf-huruf hijaiyah contoh seperti $ت$ dengan $ن$ dan lain sebagainya oleh sebab itu di era teknologi tentunya semua orang sudah akrab dengan teknologi 3dimensi (3D), sekarang hadir sebuah teknologi baru yang di sebut Augmented Reality(AR) yakni teknologi bisa mengabungkan dunia nyata dengan dunia maya yang di proyeksikan melalui prangkat elektronik.

Dengan perkembangan teknologi saat ini, belajar maupun mencari informasi tidaklah sulit dilakukan. Telah banyak cara yang dilakukan oleh peneliti terdahulu untuk membuat media pembelajaran menumbuhkan minat belajar mengenai huruf hijaiyah. salah satunya mengguakan Augmented Reality(AR) ini dengan memaduka huruf HijaIyah yang di proyeksikan 3dimensi untuk mengenal perbedaan yang terdapat pada huruf dengan aplikasi edukasi interaktif berbasis android di dalam aplikasi ini terdapat juga suara untuk membantu anak anak memahami perbedaan huruf Hijaiyah dalam makhrijul hurufnya.
\end{abstract}

Kata Kunci : Pengenalan Huruf Hijaiyah, Augmented Reality, Android

\section{PENDAHULUAN}

Di era teknologi saat ini semua orang sudah akrab dengan teknologi tiga dimensi (3D) dimana implemen tasi dari objek tiga dimensi (3D) tidak hanya saja sebuah gambar melainkan berupa text video dan lain-lain. Augmented Reality (AR) adalah teknologi yang dapat menggambarkan dan menggabungkan dunia nyata dan dunia maya yang diproyeksikan melalui perangkat elektronik dan bisa digunakan tidak hanya di platform deskstop bahkan bisa digunakan di dalam platform mobile [1].

Pada usia ini anak anak lebih mudah untuk memahami dan merekam sesuatu di otak atau memorinya, dibandingkan di usia tua atau dewasa pengenalan huruf hijaiyah pada anak-anak memerlukan metode pembelajaran yang efektif dan menyenangkan, agar anak tidak merasa bosan sehingga anak tetap fokus pada pelajaran. Dengan demikian, suatu tujuan pembelajaran akan tercapai dengan baik. Dengan menggunakan metode marker based tracking. Marker berfungsi sebagai penanda suatu informasi.

Dengan aplikasi pengenalan huruf Hijaiyah AlQuran selain dapat meningkatkan minat belajar siswa tentang huruf hijaiyah ini dengan pembelajaran dan pengetahuan berbagai macam huruf tentunya yang ada di dalam huruf hijaiyah ini.

\section{TINJAUAN PUSTAKA}

\subsection{Penelitian Terdahulu}

Menurut Yosep Agus, Suryo Adi Wibowo, Miftahur Rokhman, dan Kartiko Ardi pada penelitian berjudul "Implementasi Aplikasi Penghtungan Kebutuhan Kalori Penderita Diabetes Melitus Di Lingkungan Klinik" dengan adanya aplikasi yang di buat dapat meminimalisir kesalahan perhitungan dengan adanya kecerdasan buatan yang menggunakan metode fuzzy logic yang di terapkan memperkirakan jumlah asupan kalori penyakit diabetes mellitus secara konsisten dan melalui hasil wawancaranya $80 \%$ tenaga medis di klinik merasa terbantu dan untuk operasional sistem sangat mudah[2].

Menurut Latius Hermawan dan Mochamad Hariadi yang berjudul Pemanfaatan Augmented Reality Sebagai Media Informasi Kampus Menggunakan Brosur bahwa pemanfaatan Augmented Reality sebagai media informasi kampus dengan menggunakan brosur akan dapat dibuat dengan baik menggunakan Unity3D dan Vuforia sebagai tools. informasi yang belum termuat dalam brosur dapat ditampilkan secara virtual tanpa tambahan brosur lainnya. Sehingga penghematan bahan baku dan biaya juga dapat dilakukan. Penelitian ini menggunakan juga menggunakan Augmented Reality sebagai mendemokan denah lokasi di dalam kampus terkait .[3] 
Menurut Afif Anshari dengan judul Display Produk Daihatsu Menggunakan Augmented Reality Berbasis Android dalam jurnal ini di sebutkan bahwa penelitianya terkait dengan mendeskripsikan sebuah produk dari Pt.Astra Daihatsu Motor pendeteksi marker yang di buat berjalan dengan baik namun harus di perhatikan jarak antara kamera handphone dengan marker yang di buat sehingga mendapatkan sebuah gambar marker yang bagus [4].

Menurut Qumillaila, Hana dan Zulfiani pada penelitian yang berjudul "Pengembangan Augmented Reality Versi Android Sebagai Media Pembelajaran Sistem Ekresi Manusia" Penelitian ini bertujuan untuk mengembangkan media pembelajaran biologi menggunakan teknologi augmented reality versi Android, serta menguji daya gunanya pada siswa dan guru biologi [5]

\subsection{Huruf HijaIyah}

Huruf merupakan unit terkecil dalam susunan sebuah lafaz atau pun kata. supaya menghasilkan suatu makna, sebuah huruf harus dirangkaidengan huruf-huruf yang lain dan membentuk beragam kosakata. Istilah huruf hijaiyah sendiri diambil dari istilah asal bahasa Arabnya الهجائية, ia berakar dari لهاء -هجا- يهجو yang bermakna mengeja atau ejaan.

Selain bermakna ejaan dalam bahasa arab huruf hijaiyah Sebagai bagian terkecil dalam bahasa arab, huruf hijaiyah tentu menjadi syarat awal untuk seseorang dapat membaca kitab suci Alquran. Bahkan mengenal huruf-hurufnya menjadi pelajaran yang paling awal diajarkan ketika baru belajar tentang agama islam.[6]

\subsection{Jumlah Huruf HijaIyah}

Ada tiga acuan perhitungan berbeda terkait dengan jumlah huruf hijaiyah yaitu 28,29 dan 30 . Namun dari ketiga ini sebenarnya hanya di dasarkan pada menghitung huruf tertentu sebagai huruf yang mandiri, atau memasukkan dalam bagian huruf yang lain. Jika mengambil huruf terbanyak, maka jumlah keseluruhan adalah 30 huruf, dengan rincian tabel sebagai berikut:

\begin{tabular}{|c|c|c|c|}
\hline No & $\begin{array}{c}\text { Huruf } \\
\text { HijaIyah }\end{array}$ & $\begin{array}{l}\text { Nama } \\
\text { Huruf }\end{array}$ & $\begin{array}{c}\text { Tranliterasi } \\
\text { Latin }\end{array}$ \\
\hline 1 & 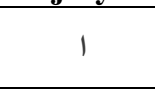 & Alif & $\begin{array}{c}\text { Tidak di } \\
\text { lambangkan }\end{array}$ \\
\hline 2 & ب ب & Bha' & $\mathrm{B}$ \\
\hline 3 & $ت$ & Ta' & $\mathrm{T}$ \\
\hline 4 & $\dot{\sharp}$ & Tsa' & Ts \\
\hline 5 & ج & Jim & $\mathrm{J}$ \\
\hline 6 & $\tau$ & $\mathrm{Ha}{ }^{\prime}$ & $\mathrm{H}$ \\
\hline 7 & $\dot{\tau}$ & Kha' & $\mathrm{KH}$ \\
\hline 8 & I & Dal & $\mathrm{D}$ \\
\hline 9 & $\dot{j}$ & Dzal & DZ \\
\hline 10 & J & $\mathrm{Ra}^{\prime}$ & $\mathrm{R}$ \\
\hline 11 & j & $\mathrm{Za}$ & $\mathrm{Z}$ \\
\hline 12 & س - س & Sin' & $\mathrm{S}$ \\
\hline
\end{tabular}

\begin{tabular}{|c|c|c|c|}
\hline 13 & ش ش - م & Syin' & SY \\
\hline 14 & ص & Shad & SH \\
\hline 15 & 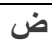 & Dha' & DH \\
\hline 16 & $b$ & Tha' & TH \\
\hline 17 & ط & Zha' & $\mathrm{ZH}$ \\
\hline 18 & $\varepsilon$ & 'Ain & $\begin{array}{c}\text { '(tanda petik di } \\
\text { lanjutkan huruf } \\
\text { vokal seperti 'A- } \\
\text { 'I-'U Jika huruf } \\
\text { berharakat }\end{array}$ \\
\hline 19 & $\dot{\varepsilon}$ & Ghain & GH \\
\hline 20 & ف & $\mathrm{Fa}$ & $\mathrm{F}$ \\
\hline 21 & ق & Qaf & $\mathrm{Q}$ \\
\hline 22 & ك & Kaf & $\mathrm{K}$ \\
\hline 23 & J & Lam & $\mathrm{L}$ \\
\hline 24 & b & Mim & $\mathrm{M}$ \\
\hline 25 & ن & Nun & $\mathrm{N}$ \\
\hline 26 & 9 & Waw & $\mathrm{W}$ \\
\hline 27 & 0 & $\mathrm{Ha}$ & $\mathrm{H}$ \\
\hline 28 & 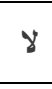 & Lam alif & $\begin{array}{l}\text { La(dengan bunyi } \\
\text { agak panjang) }\end{array}$ \\
\hline 29 & $\&$ & Hamzah & $\begin{array}{c}\text { A,I,U Sesuai } \\
\text { dengan harakat, } \\
\text { setelahnya } \\
\text { ditambahkan } \\
\text { tanda peti(') }\end{array}$ \\
\hline 30 & ي & $\mathrm{Ya}^{\prime}$ & Ya-Yi-Yu \\
\hline
\end{tabular}

\subsection{Augmented Reality}

Augmented Reality (AR) adalah dimana 2 lingkungan yang di gabungkan yaitu terdiri dari dunia nyata dan dunia virtual oleh komputer sehingga hampir tidak ada batas diantara keduanya. Dengan adanya teknologi AR(augmented reality), lingkungan sekitar akan dapat berinteraksi masuk ke dalam bentuk digita (virtual).informasi tentang objek yang menjadi satu dengan lingkungan skitar dapat di tambahkan ke dalam sebuah sistem AR(augmented reality) yang kemudain akan di tampilkan pada layar komputer dan handphone atau smartphone secara real-time atau benar benar terjadi dan informasi tersebut berupa gambar video atau bahkan game secara nyata. [7]

Teknologi AR ini dapat menyisipkan suatu informasi tertentu ke dalam dunia maya dan menampilkannya di dunia nyata dengan bantuan perlengkapan seperti webcam, komputer, Smartphone, maupun kacamata khusus. Metode metode yang terdapat di dalam augmented reality di bawah ini adalah salah satunya :

\section{Marker Based Tracking}

Marker merupakan ilustrasi antara hitam dan putih dengan batas hitam tebal maupun tipis dan dengan latar putih. Komputer akan mengenali posisi dan orientasi setiap marker dan membuat virtual 3D yaitu titik koordinat $(0,0,0)$ dengan terdiri dari tiga sumbu yaitu X,Y dan Z. Marked Based Tracking ini sudah di kembangkan mulai tahun 1980-an dan pada 
awal 1990 dan mulai di pakai untuk penggunaan Augmented Reality.

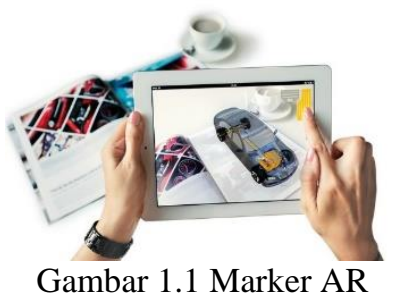

\subsection{Vuforia $S D K A R$}

Vuforia adalah salah satu SDK (Software Development Kit) untuk AR (Augmented Reality) untuk perangkat mobile dan di gunakan di dalam Unity Egine yang memungkinkan pembuatan AR di dalamnya, Dan dulunya di kenal dengan QCAR(Qualcom Company Augmented Reality).Vuforia SDK Menggunakan teknologi yang berbasis Computer Vision untuk mengenali dan memindai gambar marker yang di buat (target image) dan objek 3D sederhana, seperti kotak, secara langsung.Kemampuan menganalisa citra memungkinkan pengembang aplikasi utnuk mengatur posisi dan orentasi maya objek, seperti $3 \mathrm{~d}$ model dan media lainnya, dan dalam keterkaitanya dengan gambar atau object dunia nyata ketika di akses melalui kamera perangkat. Objek dunia maya kemudian di lacak posisi dan orientasinya dari gambar secara langsung sehingga persepektif pengguna pada objek sesuai dengan pada persepektif Target Image, sehingga muncul bahwa objek virtual adalah bagian dari dunia nyata pada saat ini.

SDK Vuforia mendukung berbagai jenis target 2D dan 3D termasuk Target Gambar 'markerless', 3D Multi target konfigurasi, dan bentuk Marker Frame. Fitur tambahan yang terdapat pada SDK termasuk halangan menggunakan 'Tombol virtual', runtime pemilihan yang terdapat dalam gambar target, dan kemampuan untuk membuat dan menkonfigurasi ulang pada pemograman tersebut pada saat di jalankan. Vuforia merupakan penyedia API(application programming interface) di $\mathrm{C}++$, Java, Objective-C. SDK(software development kit) mendukung untuk membangun aplikasi IOS dan Android menggunakan vuforia karena itu cocok dengan berbagai perangkat mobile.

Qualcomm Augmented Reality memberikan beberapa keuntungan seperti :

a. Teknologi computer vision untuk menyelaraskan gambar yang tercetak dan object 3D.

b. Mendukung beberapa alat development seperti Eclipse, Android, Xcode. Selain itu, QCAR juga menawarkan development dan distribusi yang gratis .[8]

\subsection{Image Target}

Image Target ialah gambar yang hanya bisa di lacak dan di deteksi oleh Vuforia SDK.Vuforia SDK mengaplikasikan algoritma khusus untuk mendeteksi dan melacak fitur yang secara natural ditemukan didalam sebuah gambar. Vuforia SDK melacak Image target dengan membandingkan isi yang ada pada gambar fisik dengan gambar yang ada di dalam database aplikasi.

Ketika gambar terdeteksi, SDK akan melacak gambar selama gambar tersebut berada di sudut pandang kamera. Fitur yang bisa di pakai oleh Vuforia SDK ialah detail berbentuk sudut pada gambar. Gambar yang bisa digunakan sebagai image target harus memiliki beberapa keriteria pembuatan yaitu :

1. Memiliki format 8 atau 16-bit dan JPG atau PNG.

2. Gambar harus format JPG dan memiliki warna RGB atau grayscale

3. Memiliki resolusi minimal 320 pixel.

4. Memiliki ukuran maksimal 2 MB.

5. Gambar tidak memiliki pola yang berulang.

Setelah diunggah, secara otomatis gambar akan mendapat implementasi algoritma yang dibuat khusus oleh vuforia sehingga fitur-fitur bisa terlihat dengan jelas. [9].

\subsection{Unity 3D v2018 LTS}

Unity adalah sebuah bentuk teknologi terbaru yang meringankan dan memudahkan game develop dalam membuat game. Selain untuk merancang game , unity 3D juga dapat digunakan untuk membuat sebuah konten yang interaktif lainnya seperti visual arsitektur dan real-time $3 \mathrm{~d}$ animasi dan lain lain[10].

Grafis pada unity di buat dengan standar tingkat tinggi untuk OpenGL dan directX. Unity mendukung semua format file. Unity cocok dengan versi 64-bit dan dapat beroperasi pada Mac OS x dan windows dan dapat menghasilkan game untuk Mac, Windows, Wii, iPhone, iPad dan Android.Versi LTS(long term support).

ini adalah salah satu varian dari software unity yang mendukung pembuat aplikasi dari unity ini untuk terus mengembangkan aplikasinya tanpa takut adanya bug yang terdapat dalam software unity $3 d$ yang di pakai versi LTS(long term support) tidak memiliki fitur-fitur tambahan dna perubahan pada API di karenakan meminimalisir sebuah error API dari android build SDK/XDK setiap versi LTS ini di dukung dengan jangka waktu paling lama dua tahun[10].

\subsection{Blender}

Blender ialah salahastu software mengolah 3D untuk membuat suatu animasi dan bisa di jalankan di windows dan berbagai platform OS(operating sistem) lainnya. Blender sendiri juga sama seperti softwar 3DS Max, namun yang membedakanya ialah lebih ringan dan tidak berat dalam hal merender objek kecil sederhana dan biasanya project yang terdapat di dalam software Blender ini dapat di buka di berbagai software 3D lainnya. 
Blender juga dapat membuat game karena memilik Game Engine miliknya sendiri.[11]

\section{METODE PENELITIAN}

\subsection{Blok Diagram Sistem}

Blokdiagram adalah diagram darisebuah sistem, di mana bagian utama atau fungsi yang diwakili oleh blok dihubungkan dengan garis, yang menunjukkan hubungan dari blok.

Proses kerja pada aplikasi pengenalan huruf hijaiyah di tunjukkan pada gambar 3.1 berikut.

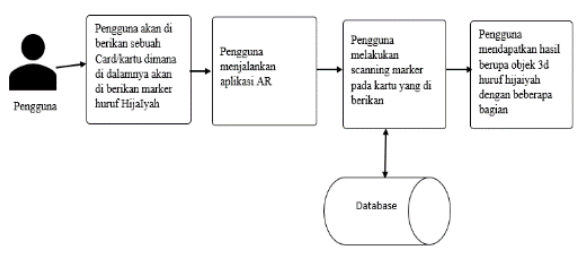

Gambar 3.1 Blok diagram sistem

Pada blok diagram system dapat diketahui langkah awal sebelum menjalankan aplikasi yaitu user mempunyai kartu yang berisi marker dan informasi mengenai huruf hijaiyah yang akan di tampilkan mengguanakan augmented reality berbasis android. Kemudian user menjalankan aplikasi dan memilih menu scaning marker, dimana marker akan di scan kemudian system akan mengambil informasi berupa objek 3D dari database.[12]

\subsection{Flowchart sistem}

Flowchart sistem ini menjelaskan proses berjalananya aplikasi seperti terlihat pada Gambar 3.2 berikut.

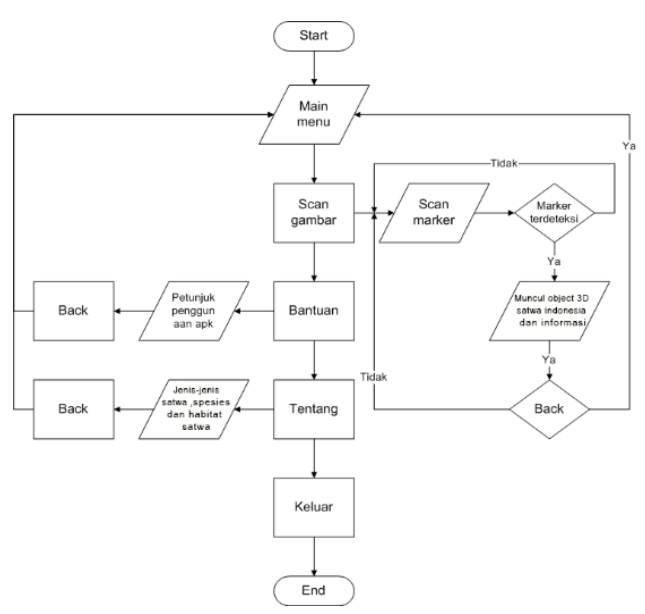

Gambar 3.2 Flowchart sistem

Pada flowchart sistem di atas proses dimulai dari start yaitu Main menu pada aplikasi. Kemudian masuk pada Main menu. Selanjutnya adalah halaman scan marker yang langsung terhubung dengan kamera smartphone. Setelah kita lakukan scan marker dan jika marker sesuai maka akan muncul objek 3D dan informasi deskripsi berupa audio yang dapat di akses melalui button narasi. Selanjutnya terdapat fitur bantuan yang berisi cara penggunaan aplikasi. Terdapat fitur tentang yang berisi deskripsi aplikasi dan profil developer. Dan proses berakhir apabila kita menekan tombol keluar aplikasi atau end pada flowchart.

\subsection{Flowchart Augmented Reality}

Flowchart augmented reality ini menjelaskan proses pembacaan marker pada sistem augmented reality itu sendiri seperti pada Gambar 3.3 berikut.

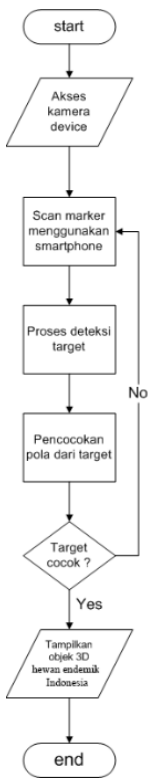

Gambar 3.3 Flowchart augmented reality

Proses pendeteksi marker di mulai dengan pembacaan marker oleh kamera smartphone. Kemudian kamera akan mendeteksi marker tersebut. Keakuratan deteksi pada marker bergantung pada beberapa hal, yaitu intensitas cahaya, jarak marker dengan kamera, dan resolusi kamera. Jika marker tidak terdeteksi, maka user harus mengatur marker dan menunjukkan kembali pada kamera. Jika marker terdeteksi maka akan muncul objek 3D dan informasi sesuai dengan marker.

\section{HASIL DAN PEMBAHASAN \\ 4.1 Pengujian Main menu}

Tampilan awal pada aplikasi ini merupakan tampilan Main menu sebelum masuk ke tampilan berikutnya di dalam tampilan ini terdapat 4 Button pertama Scan AR utnuk masuk menu Augmented Reality . Berikut adalah tampilan dari Main Menu, Quiz, Bantuan,Tentangseperti pada Gambar 4.1. 


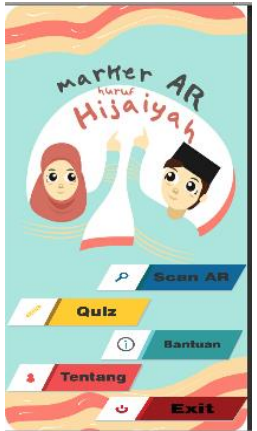

Gambar 4.1 Tampilan Main Menu

\subsection{Pengujian Tampilan Menu Quiz}

Tampilan kedua adalah pada aplikasi ini merupakan tampilan menu quiz yang akan digunakan. Pada tampilan menu ini terdapat 1 button menu yaitu Mulai seperti pada Gambar 4.2 berikut.

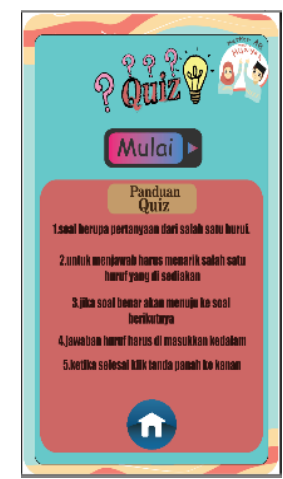

Gambar 4.2 Tampilan pilihan Bahasa

\subsection{Pengujian Tampilan Scan Marker}

Tampilan menu scan marker akan langsung tersambung dengan kamera smartphone. Pada tampilan menu mulai ini terdapat beberapa button yaitu suara hewan, suara narasi, zoom in , zoom out, rotasi, dan kembali seperti pada Gambar 4.3 berikut.

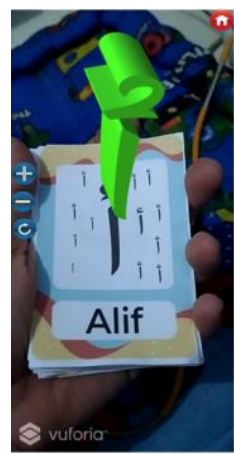

Gambar 4.3 Tampilan scan marker

Pada saat marker di hadapkan ke kamera aplikasi, aplikasi akan mendeteksi marker dan akan menampilan objek 3D, yang sebelumnya sudah teridentifikasi oleh aplikasi.

Jika marker lain atau marker yang tidak terdaftar di dalam database aplikasi, maka aplikasi tidak akan menambilkan objek apapun. Adapun desain halaman tersebut seperti pada Gambar 4.4.

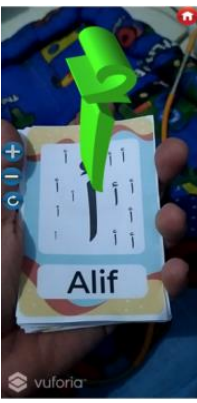

Gambar 4.4 Tampilan objek 3D Huruf HijaIyah Alif

\subsection{Pengujian Tampilan Menu Quiz}

Tampilan menu kuis menyediakan pertanyaan dalam bentuk tarik gambar yang lebih interaktif dan mudah dimengerti dengan fitur animasi apabila dapat menjawab dan di dalam menu quiz terdapat panduan cara memainkanya pertanyaan secara benar. seperti pada Gambar 4.5 berikut.

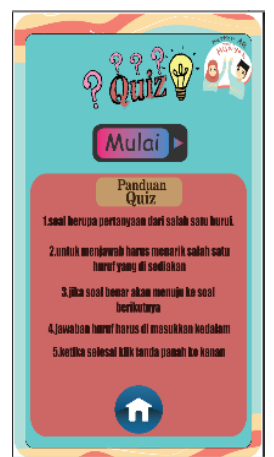

Gambar 4.5 Tampilan awal Mulai Quis

Quis tarik gambar dibuat dengan bentuk pilihan 3 kotak huruf hijaiyah berbeda pilih salah satu jawaban lalu tarik ke kotak hitam apabila benar ia akan mengeluarkan animasi agar lebih menarik dengan dilengkapi button next,prev. untuk ke quiz atau soal selanjutnya dan sebelumnya penggunaan button kembali ke menu awal kuis. seperti pada Gambar 4.6 berikut.

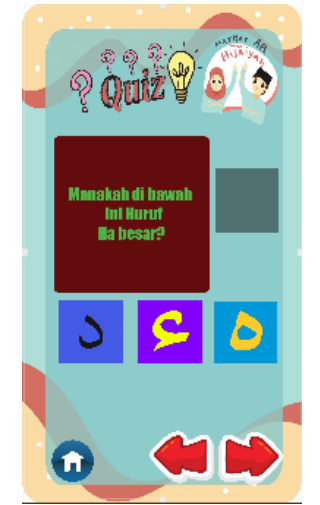

Gambar 4.6 Tampilan soal kuis 


\subsection{Pengujian Tampilan Menu Tentang}

Tampilan menu informasi atau tentang ini berisi informasi mengenai aplikasi dan profil dari pengembang aplikasi Dilengkapi dengan button kembali yang langsung mengarah pada Main menu seperti pada Gambar 4.7 berikut.

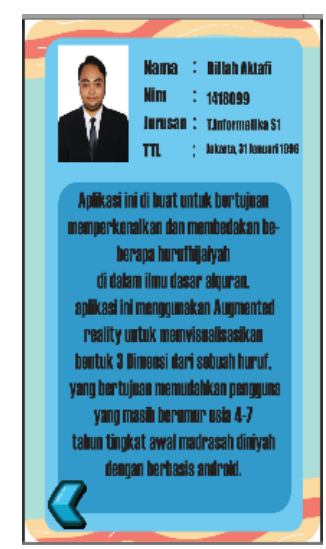

Gambar 4.7 Tampilan menu tentang

\subsection{Pengujian Tampilan Menu Bantuan}

Tampilan menu bantuan ini berisi cara penggunaan aplikasi yang dilengkapi dengan button kembali yang langsung mengarah pada tampilan ke Main menu seperti pada Gambar 4.8 berikut.

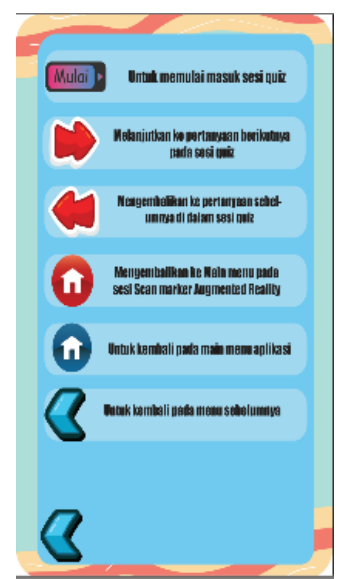

Gambar 4.8 Tampilan menu bantuan

\section{KESIMPULAN DAN SARAN}

\subsection{Kesimpulan}

Setelah dilakukanya pengujian pada aplikasi Implementasi Augmented Reality Untuk Pengenalan Hewan Endemik Indonesia berbasis Android, maka penulis mendapatkan kesimpulan sebagai berikut :

1. Marker dapat terdeteksi dengan baik jika jarak scan AR camera antara $10 \mathrm{~cm}$ sampai $30 \mathrm{~cm}$ dan memiliki intensitas cahaya cukup.

2. Aplikasi dilengkapi informasi ciri-ciri huruf dalam bentuk audio.

3. Aplikasi dilengkapi dengan quiz interaktif sebagai media pembelajaran.

4. Marker terdeteksi dengan baik apabila intensitas cahaya cukup dan tidak terlalu terang.

\subsection{Saran}

Berdasarkan penelitian yang telah dilakukan maka penulis dapat memberikan saran-saran untuk pengembangan selanjutnya karena penelitian ini masih terdapat banyak kekurangan, sehingga untuk penyempurnaan dapat ditambahkan :

1. Desain objek 3D yang lebih detail dan realistik serta tampilan UI agar semakin menarik bagi user.

2. Penambahan fitur objek huruf sambung dan audio contoh kata.

3. Pengembangan dalam bentuk VR untuk menambah minat belajar dan pengetahuan mengenai cara baca, huruf sambung, dan makharijul hurufnya.

4. Marker dari sebuah huruf harus di bedakan dari kosakata hingga pemakaian font huruf.

\section{DAFTAR PUSTAKA}

[1] Candra. (2014), Perancangan Sistem Interaksi Berbasis Teknologi Augmented Reality pada Sampul Media Promosi Cetak, Jurnal Teknologi Informasi ISSN : 1907 - 2430, volume 6, Nomor 18, Nopember 2011

[2] Yosep Agus, Suryo Adi Wibowo, Miftahur Rokhman, dan Kartiko Ardi "Implementasi Aplikasi Penghtungan Kebutuhan Kalori Penderita Diabetes Melitus Di Lingkungan Klinik" pada Sampul Cetak MNEMONIC, Jurnal MNEMONIC Vol. 1, No. 2, September 2018

[3] Latius Hermawan, Mochamad Hariadi," Pemanfaatan Augmented Reality Sebagai Media Informasi Kampus Menggunakan Brosur Seminar Nasional Teknologi Informasi dan Komunikasi 2015 (SENTIKA 2015) ISSN: 2089-9815 Yogyakarta, 28 Maret 2015

[4] Muhammad Afif Anshari (2018), Display Produk Daihatsu Menggunakan Augmented Reality Berbasis Android, JATI (Jurnal Mahasiswa Teknik Informatika) Vol. 2 No. 2, September 2018.

[5] Qumillaila, Baiq Hana Susanti, dan Zulfiani, Pengembangan Augmented Reality Versi Android Sebagai Media Pembelajaran Sistem Ekskresi Manusia , Februari 2017, Th. XXXVI, No. 1.

[6] Tgk. Muhammad Ikbal(2019). Mengenal Huruf Hijaiyah Arabl atin dan caramembaca.https://hasana.id/hurufhijaiyah/\# Mengenal_Huruf_Hijaiyah_Arab_latin_dan_car a_membacanya(Kamis, 23 May 201911.10 AM).

[7] S. Feiner, B. Macintyre, and D. Seligmann, "Knowledge-based Augmented Reality," Commun ACM, vol. 36, no. 7, pp. 53-62, Jul. 1993.

[8] Pratikno Heri. Kontrol Gerakan Objek 3D Augmented Reality Berbasis Titik Fitur Wajah 
dengan POSIT. JNTETI, Vol. 4, No.1. 2301 4156.

[9] Wikipedia.Android(sistemoperasi). https://id.wikipedia.org/wiki/Android_(sistem_o perasi) (Rabu, 10 May 2019 09.47 PM).

[10] Rudisantoso. (2016). jbptunikompp-gdlrudisantos-35430-7-unikom_r-i.

https://elib.unikom.ac.id/download.php?id=2576 20 (Selasa, 4 Juni 2019 11.12 PM).

[11] Tin Megali (2017). Tips dan Trik Augmented Reality Dengan Unity dan
Vuforia.https://gamedevelopment.tutsplus.com/i $\mathrm{d} /$ tutorials/vuforia-tips-and-tricks-on-unity-cms-28744(Selasa, 14 May 2019 10.11PM).

[12] Yulianto, Nanang (2012), Pembuatan Game 3 Dimensi Lost In Jungle dengan Menggunakan Unity 3D Game Engine, Diakses 21 Semptember2018,darihttp://repository.amikom.a c.id/files/Publikasi_10.21.0535(Rabu, 4 Juli 2019 09.45 PM).. 